\title{
Corporate Governance And Accuracy Level Of Financial Distress Prediction Models
}

\author{
Alba Maria Priego de la Cruz, University of Castilla-La Mancha, Spain \\ Montserrat Manzaneque Lizano, University of Castilla-La Mancha, Spain \\ Elena Merino Madrid, University of Castilla-La Mancha, Spain
}

\begin{abstract}
This investigation verifies the impact of corporate governance measure on the likelihood of financial distress on the Spanish Stock Exchange for the time period from 2007 to 2012. The authors applied an empirical study with panel data and conducted regression logistic models with the objective to calculate different measures of goodness of fit. The results of this study show that the prediction power of the financial distress models improves with the incorporation of some corporate governance measures.
\end{abstract}

Keyword: Corporate Governance; Ownership Structure; Board Structure; Financial Distress; Logistic Regression

\section{INTRODUCTION}

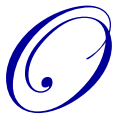

ne of the most questioned elements in the actual economic crisis has been the role of corporate governance in the development of companies' decline. Specifically, previous research emphasizes the agency problems between managers and shareholder, when the companies are in a context of financial distress situation, and the role of board of directors in its function of monitoring and controlling managerial opportunism behavior in those cases. In this sense, a large body of literature has highlighted the importance of corporate governance and its influence on the likelihood of financial distress or bankruptcy (Donker et al., 2009; Fich \& Slezak, 2008; Lajili \& Zéghal, 2010; Mangena \& Chamisa, 2008). However, these researchs have been limited to certain context, such as U.S., Taiwan and China, and on bankruptcy or legal processes. For this reason, the extension of analysis to other geographic context and to other financial distress situations different to bankruptcy contributes to complement the existing literature.

The Spanish context has corporate governance characteristics that differ from other contexts, such as unitary board system, ownership concentration, and voluntary good governance practices. In this context, the literature asserts that it is more likely that there is important agency conflict in financial distress situations. So, the study of relationship between corporate governance and financial distress of Spanish firms provides evidence for this type of contexts. Therefore, this research aims to verify if the incorporation of corporate governance measure in the financial distress prediction model increases the accuracy level compared to models based solely on economic and financial data.

The authors used data from Spanish-listed companies between 2007 and 2012 and applied panel data statistical methodology in order to answer the main research objective as explained above. Results corroborate that, also in contexts of concentrated ownership and unitary board system, where the ability of monitoring and control on managers by board is lower than dispersed ownership contexts, the accuracy level of financial distress prediction models increases as a result of the addition of corporate governance variables. 


\section{CORPORATE GOVERNANCE AND FINANCIAL DISTRESS}

The ownership structure and the ability of the board to act efficiently have been regarded as important determinants of businesses' financial distress. So, the role of ownership structure and board composition and structure on the likelihood of business financial distress should be examined.

\section{Ownership Structure}

Previous studies provide arguments about the influence of ownership concentration and board ownership on the likelihood of financial distress. Regarding ownership concentration, since large shareholders could suffer great losses for their participation in a financially distressed company, it is expected that they exercise an important monitoring function on opportunistic management behavior, reducing the likelihood of incurring in a financial distress situation (Donker et al., 2009; Elloumi \& Gueyie, 2001). Respecting board ownership, the convergence theory argues that the participation of the board of directors in shareholding is also a powerful incentive to achieve the alignment of their interests with those of other shareholders (Shleifer \& Vishny, 1997); that is, maximizing the value of shares. Following this idea, it is expected that directors will fight for the survival of the firms in which they hold shares.

\section{Board Structure}

The business failure literature shows that weak or poor corporate governance increases the probability to opportunistic behavior of management or controlling shareholders to act in their own interest, extracting wealth from other shareholders (La Porta et al., 2000; Johnson et al., 2000) and increasing the likelihood of financial distress. The board of directors' weakness has been measured through its composition and structure; that is, independence of its members and number of directors (size). The independence of the board has been measured according to the separation of duties of the CEO and Chairman and proportion of independent directors on the board. Regarding the first, there is no consensus about the effect of CEO duality (same person assumes the CEO and Chairman functions) on likelihood of financial distress. The positive effect (CEO duality increases the financial distress' likelihood) is attributed to lack of independence and monitoring effectiveness on managers by board (Baysinger \& Hoskisson, 1990; Jensen M., 1993). Contrarily, the negative effect (CEO duality reduces the likelihood of financial distress) is associated to strong leadership and control unit, which improves the transmission of information, reduces coordination costs, and avoids the emergence of potential conflicts of interest between CEO and Chairman (Davis et al., 1997; Donaldson \& Davis, 1991). Despite this lack of consensus, the results demonstrated the influence of CEO duality on the likelihood of financial distress, in one or another direction.

About the presence of independent directors on the board, literature points out that they are more effective to monitor managers' opportunistic behaviors (Chang, 2009; Daily, 1995; Fich \& Slezak, 2008). According to this approach, as the empirical evidence demonstrates, firms with higher proportion of outside directors are less likely to fail due to they are more efficient in imposing the necessary measures to help overcome a possible failure situation (Deng \& Wang, 2006; Elloumi \& Gueyie, 2001; Fich \& Slezak, 2008).

Respecting board size, previous literature supports two different perspectives. On the one hand, the Resource Dependence Theory argues that larger boards offer various advantages associated with the company's ability to access the resources and information held by the directors and that might be needed to achieve the business objectives (Pearce \& Zahra, 1992; Pfeffer, 1973). From this perspective, the size of the board would be negatively associated with the likelihood of business failure. In contrast, previous studies reveal some problems related to big size of the board, such as greater discretion of its members to meet their particular interests to the detriment of the general interest of the company (Chaganti et al., 1985) or lack of effectiveness when turbulent economic environments require a change in strategic direction (Goodstein et al., 1994). From this point of view, smaller boards are more effective in the implementation of mechanisms for corporate control (Jensen, 1993), thereby decreasing the chances of the company to achieve unstable economic and financial situations (Fich \& Slezak, 2008). 
In this sense, the authors suggest that the addition of corporate governance variables to the financial distress prediction models, built with financial ratios, contributes to increase their level of accuracy. So, they propose the following research hypothesis:

H1. Corporate governance variables help to improve the level of accuracy of traditional financial distress prediction models (based solely on financial ratios).

\section{ECONOMETRIC SPECIFICATION AND RESULTS}

In order to test the financial distress prediction models' improvement by incorporation of corporate governance measures, data were collected from 70 Spanish-listed firms during the time period from 2007 to 2012 and an empirical study with panel data and applied cross-sectional statistical methodology, such as a binary logistic regression, was conducted. For this, two logistic regression models were used:

(1) Model based on Financial Data (FDL) (Pindado et al., 2008):

$\mathrm{FD}=\beta_{0}+\beta_{1} \mathrm{PROF}+\beta_{2} \mathrm{FE}+\beta_{3} \mathrm{RE}+\mathrm{d}_{\mathrm{t}}+\eta_{\mathrm{it}}+\mathrm{u}_{\mathrm{it}}$

(2) Model based on Financial Data and Corporate Governance Variables (FDLCG):

$\mathrm{FD}=\beta_{0}+\beta_{1} \mathrm{PROF}_{\mathrm{it}}+\beta_{2} \mathrm{FE}_{\mathrm{it}}+\beta_{3} \mathrm{RE}_{\mathrm{it}}+\beta_{4} \mathrm{OWNERSIG}_{\mathrm{it}}+\beta_{5} \mathrm{OWNERD}_{\mathrm{it}}+\beta_{6} \mathrm{CEOD}_{\mathrm{it}}+\beta_{7} \mathrm{BO}_{\mathrm{it}}+\beta_{8} \mathrm{BS}_{\mathrm{it}}+\beta_{9} \sum \mathrm{CV}_{\mathrm{it}}+$ $\mathrm{d}_{\mathrm{t}}+\eta_{\mathrm{i}}+\mathrm{u}_{\mathrm{it}}$

where $\mathbf{F D}=$ Financial distress. A financial distress situation is considered when a firm meets some of the following conditions: (1) its earnings before interest and taxes depreciation and amortization (EBITDA) are lower that its financial expenses for two consecutive years and/or (2) a fall in its market value occurs between two consecutive periods. Under this approach, the authors have constructed a binary dependent variable which takes the value 1 if the company meets one of the above criteria and 0 , otherwise.

PROF: profitability measured as earnings before interest and taxes by the total assets at the beginning of the period

FE: financial expenses measured as financial expenses by the total assets at the beginning of the period

RE: retained earnings is total earnings of a firm by the total assets at the beginning of the period

OWNERSIG: ownership concentration measured as the percentage of shares owned by large shareholders

OWNERD: board ownership is the percentage of shares owns by members of the board of directors

CEOD: CEO duality that is measured with a dummy variable which takes the value 1 when there is duality and 0 in other cases

BO: outside board measured as the proportion of independent director on the total number of directors

BS: board side represents the numbers of members on board

CV: control variables are firm size (logarithm of total assets) and industry

i: the cross sectional unit (company, $\mathrm{i}=1, \ldots, \mathrm{N}$ )

t: the time period (year, $\mathrm{t}=1, \ldots, \mathrm{T}$ )

$\mathbf{d}_{\mathbf{t}}$ : the time effect

$\eta_{\mathrm{i}}:$ :represents the individual effect

$\mathbf{u}_{\mathrm{it}}$ : the random disturbance 
Table 1 shows the results for the logistic regression models and their adjusted goodness measures.

Table 1: Logistic Regression Models

\begin{tabular}{|c|c|c|c|c|c|c|}
\hline & \multicolumn{3}{|c|}{ FDL } & \multicolumn{3}{|c|}{ FDLCG } \\
\hline Variables & Beta & Sig. & Odds Ratio & Beta & Sig. & Odds Ratio \\
\hline PROF & -3.851 & 0.000 & .0212 & -4.241 & 0.000 & 0.014 \\
\hline FE & 10.931 & 0.038 & 55.723 & 16.665 & 0.008 & 2.407 \\
\hline $\mathbf{R E}$ & -0.111 & 0.684 & 0.8951 & -0.239 & 0.439 & 0.787 \\
\hline OWNERSIG & - & - & - & 0.5812 & 0.148 & 1.788 \\
\hline OWNERD & - & - & - & -1.120 & $\mathbf{0 . 0 3 0}$ & 0.325 \\
\hline CEOD & - & - & - & 0.494 & 0.057 & 1.639 \\
\hline BO & - & - & - & -1.081 & 0.136 & 0.339 \\
\hline BS & - & - & - & 0.141 & 0.751 & 1.014 \\
\hline LOGTA & - & - & - & -0.247 & 0.020 & 0.780 \\
\hline INDUSTRY (Dummies) & - & - & - & - & - & - \\
\hline Constant & -0.391 & 0.190 & - & 4.49 & 0.017 & - \\
\hline -2 Log Likelihood & \multicolumn{3}{|l|}{-266.153} & \multicolumn{3}{|l|}{-255.454} \\
\hline McFadden R Squared Adjusted & \multicolumn{3}{|l|}{0.047} & \multicolumn{3}{|l|}{0.048} \\
\hline R Cuadrado de Nagelkerke & \multicolumn{3}{|l|}{0.137} & \multicolumn{3}{|l|}{0.197} \\
\hline $\begin{array}{l}\text { Percent Correct Prediction } \\
\text { (Noted: No-Predicted: No) } \\
\text { Specificity }\end{array}$ & \multicolumn{3}{|l|}{$54.26 \%$} & \multicolumn{3}{|l|}{$60.11 \%$} \\
\hline $\begin{array}{l}\text { Percent Correct Prediction } \\
\text { (Noted: Yes. Predicted) } \\
\text { Sensitivity }\end{array}$ & \multicolumn{3}{|l|}{$71.98 \%$} & \multicolumn{3}{|l|}{$78.45 \%$} \\
\hline Overall Percentage Prediction & \multicolumn{3}{|l|}{$64.05 \%$} & \multirow{2}{*}{\multicolumn{3}{|c|}{$70.24 \%$}} \\
\hline ROC Curve & \multicolumn{3}{|l|}{0.6918} & & & 0.7305 \\
\hline
\end{tabular}

Source: Authors' own

The measures of goodness of fit show that both models (Model based on Financial Data (FDL) and Model based on Financial Data and Corporate Governance Variables (FDLCG)) have good overall results. However, on the one hand, although the square of $\mathrm{R}$ and McFadden Nalgerkerke indicate an acceptable overall fit, it is slightly higher for the model that includes the variables of corporate governance (FDLGC) than for the model which has only economic and financial variables. This is due to the specificity of the models; that is, the probability of correctly determining a stable financial position, which is $54.26 \%$ in the FDL model compared to $60.11 \%$ in the FDLCG model. All of this is observed in the ROC (Receiver Operating Characteristic) curves.

On the other hand, the overall accuracy percentage of prediction of a financial distress situation is improved in the model that has the corporate governance variables being $70.24 \%$ compared to $64.05 \%$ of the model that has only economic and financial variables.

For the above-mentioned, the authors conclude that the inclusion of corporate governance variables in a model with solely financial data increases the prediction capacity of a financial distress situation. Therefore, these results confirm Hypothesis 1.

\section{CONCLUSIONS}

The findings show that the incorporation of corporate governance measures in financial distress prediction models, based solely on financial variables, improves the accuracy level of these models, even though it may seem that, in contexts of concentrated ownership and unitary board systems, the effectiveness of corporate governance measures is more limited than in other contexts.

These results should be of interest to rating agencies and financial institutions in order to improve their insolvency risk prediction models by incorporation of corporate governance variables. 


\section{ACKNOWLEDGEMENTS}

The presentation of a previous version of this paper to the Clute Institute International Academic Conference 2014, Munich (Germany) has been funded with a grant from the "Catedra Santander en RSC de la UCLM"

\section{AUTHOR INFORMATION}

Alba María Priego de la Cruz is a Lecturer in the Department of Business Administration in the Faculty of Social Sciences at the University of Castilla-La Mancha in Spain. She teaches courses in cost and financial accounting for undergraduate students. She received her Ph.D. in Financial Economics and Accounting in 2012 from the University of Castilla-La Macha. Her main research interests are in financial analysis of business failure. Her publications have appeared in journal such as Academia Revista Latinoamericana de Administración, Pecunia, Revista de Contabilidad y Dirección, Strategy \& Management Business Review and Seminario de Ciencias Sociales of the Universidad of Castilla-La Mancha. Email: AlbaMaria.Priego@uclm.es.

Montserrat Manzaneque Lizano is a Lecturer of Accounting in the Faculty of Social Sciences at the University of Castilla-La Mancha (UCLM) in Spain. She completed her degree in Business in 2000 and got her Ph. D. in Business Administration in 2006, both in the University of Castilla-La Mancha. Her thesis dealt with logistic models to predict the business failure in different phases of difficulty. She has published in national and international journals, such as Innovar, African Journal of Business Management, Revista Europea de Dirección y Economía de la Empresa and Strategy \& Management Business Review. Email: Montserrat.MLizano@uclm.es.

Elena Merino Madrid is a Lecturer of Accounting in the Faculty of Law and Social Sciences at the University of Castilla-La Mancha in Spain. She completed her degree in Business in 1998 and got her Ph. D. in Business Administration in 2007, both at University of Castilla-La Mancha. Her thesis dealt with stock options from the standpoint of financial, economic and accounting and she received the award for the best thesis on accounting. Her work has been published in national and international journals such as Academia Revista Latinoamericana de Administración, Innovar, Contaduría y Administración, Revista de Contabilidad y Tributación, and the African Journal of Business Management. Email: Elena.Merino@uclm.es.

\section{REFERENCES}

1. Baysinger, B., \& Hoskisson, R. (1990). The Composition of Boards of Directors and Strategic Control: Effects on Corporate Strategy. The Academy of Management Review, 15(1), 72-87.

2. Chang, C. (2009). The corporate governance characteristics of financially distressed firms: evidence from Taiwan. Journal of American Academy of Business, 15(1), 125-132.

3. Chaganti, R., Mahajan, V., \& Sharma, S. (1985). Corporate board size, composition and corporate failures in retailling industry. Journal of Management Studies, 22(4), 400-417.

4. Daily, C. (1995). An empirical examination of the relationship between CEOs and directors. Journal of Business Strategies, 12(1), 50-68.

5. Davis, J.H., Choorman, F., \& Donaldson, L. (1997). Toward a stewardship theory of management. Academy of Management Review, 22(1), 20-47.

6. Deng, X., \& Wang, Z. (2006). Ownership Structure and Financial Distress: Evidence from Public-Listed Companies in China. International Journal of Management, 23(3), 486-502.

7. Donaldson, L. \& Davis, J.H. (1991). Stewardship Theory or Agency Theory: CEO governance and shareholder returns. Australian Journal of Management, 16(1), 49-64.

8. Donker, H., Santen, B., \& Zahir, S. (2009). Ownership Structure and the Likelihood of Financial Distress in the Netherlands. Applied Financial Economics, 19(21), 1687-1696.

9. Elloumi, F., \& Gueyie, J. (2001). Financial Distress and Corporate Governance: An Empirical Analysis. Corporate Governance, 1(1), 15-23.

10. Fich, E., \& Slezak, S. (2008). Can Corporate Governance Save Distressed Firms from Bankruptcy? An Empírical Analysis? Review of Quantitative Finance and Accounting, 30(2), 225-251.

11. Goodstein, J., Gastom, K., \& Boeker, W. (1994). The effects of board size and diversity on strategic change. Strategic Management Journal, 15(3), 241-250. 
12. Jensen, M. (1993). The Moder Industry Revolution, Exit, and the Failure of Internal Control Systems. Journal of Finance, 48(3), 831-880.

13. Johnson, S., Boone, P., Breach, A., \& Friedman, E. (2000). Corporate Governance in the Asian Financial Crisis. Journal of Financial Economics, 58, 141-186.

14. Lajili, K., \& Zéghal, D. (2010). Corporate governance and bankruptcy filing decisions. Journal of General Management, 35(4), 3-26.

15. La Porta, R., Lopez-de-Silanes, F., Shleifer, A., \& Vishny, R. (2000). Investor Protection and Corporate Governance. Journal of Financial Economics, 58, 3-27.

16. Mangena, M., \& Chamisa, E. (2008). Corporate governance and incidences of listing suspension by the JSE Securities Exchange of South Africa: An empirical analysis. The International Journal of Accounting, 43(1), 28-44.

17. Pearce, J., \& Zahra, S. (1992). Board compensation from a strategic contingency perspective. Journal of Management Studies, 29(4), 411-438.

18. Pfeffer, J. (1973). Size, composition and function of hospital Board of Directors: a study of organization environment linkage. Administrative Science Quarterly, 18(3), 349-364.

19. Pindado, J., Rodrigues, L., \& De la Torre, C. (2008). Estimating Financial Distress Likelihood. Journal of Business Research, 61(9), 995-1003.

20. Shleifer, A., \& Vishny, R. (1997). A Survey of Corporate Governance. Journal of Finance, 52(2), 737-783. 